\title{
Job strain in different types of employment affects the immune response
}

\author{
Paolo Boscolo ${ }^{\mathrm{a}}$ Laura Forcella ${ }^{\mathrm{a} *}$, Marcella Reale ${ }^{\mathrm{b}}$, Giovina Vianale ${ }^{\mathrm{b}}$, Uliano Battisti ${ }^{\mathrm{c}}$, Roberta \\ Bonfiglioli $^{\mathrm{d}}$, Michela Cortini ${ }^{\mathrm{e}}$, Luca Di Giampaolo ${ }^{\mathrm{a}}$, Angela Di Donato ${ }^{\mathrm{a}}$, and Silvana Salerno ${ }^{\mathrm{f}}$ \\ ${ }^{a}$ Occupational Health Unit, University "G. D'Annunzio" of Chieti-Pescara Italy \\ ${ }^{b}$ Department of Oncology and Experimental Medicine, "G. D'Annunzio" University of Chieti-Pescara (Italy), \\ ${ }^{c}$ INAIL Abruzzo,L'Aquila Italy \\ ${ }^{d}$ Section of Occupational Medicine, Department of Internal Medicine, Geriatrics and Nephrology, Alma Mater \\ Studiorum-University of Bologna, Bologna Italy \\ ${ }^{e}$ Faculty of Psichology, University "G. d'Annunzio" of Chieti-Pescara, Chieti Italy \\ ${ }^{f}$ ENEA, Roma (Italya Journal Production Department, IOS Press, Nieuwe Hemweg 6b, 1013 BG, Amsterdam, The \\ Netherlands
}

\begin{abstract}
The immune system, in cooperation with neuroendocrine functions, defends from cancer and infections mainly by the activity of blood natural killer (NK) cells. Blood NK activity may be influenced by the type of employment since work is the central part of life; moreover, job stress is a situation affecting both neuroendocrine and immune systems. This study examines anxiety (by STAI 1 and 2), job strain (by the Karasek's JCQ) and blood NK activity (by an in vitro radio-isotopic method) of 134 male workers. These men, over 38 years old with stable employment, were working in factories, in construction yards, in offices, as hospital attendants or as self-employed craftsmen. Workers in factories and in construction yards, with high job strain, showed lower NK activity, while office employees, with low job demand, and craftsmen with low anxiety and elevated decision latitude, showed higher NK activity; the level of NK activity of the hospital attendants was between the other groups. In conclusion, this study confirms that the type of employment, related to job stress, affects blood NK activity. Moreover, blood NK activity may be used in the bio-monitoring of workers at high risk.
\end{abstract}

Keywords: occupational stress, anxiety, NK activity

\section{Introduction}

The immune system exerts, in cooperation with neuroendocrine functions, an important role in the prevention of carcinogenesis and infections. The activity of the immune system is exerted mainly through the mechanisms of the blood natural killer (NK) cells $(1,2)$. NK cytotoxic mechanisms are influenced both by environmental stimulations and mental health status $(2,3)$. Reduced blood NK activity was reported in young adults with depressive disorders (4), in young adults with poor lifestyle and mental instability (1) and in young adults with unemployment (5).
Occupational stress may derive from work environmental conditions strictly related to working activities and from additional conditions such as low social support, repetitive work without gratification or shift work (6). Reduced blood NK activity was observed in Japan in emergency-room physicians and nurses with a high work load and/or frequent night shifts $(7,8)$ as well as in Italy in staff university with high occupational stress or perception of job insecurity (9).

The purpose of this study is to investigate in five groups of male workers, with different types of stable employment, the levels of perception of anxiety and occupational stress along with the efficiency of the

${ }^{*}$ Corresponding author. E-mail: laurafox1@virgilio.it 
immune response, in particular of the blood NK activity.

\section{Materials and Methods}

134 men with age ranging between 38 and 62 years with five different types of jobs were investigated. Eighteen were working in constructions yards, 40 in different factories (specifically: 15 in textiles, 15 in metal works, 8 in electronics, 2 in a paper industry), 20 in hospitals as attendants, 14 were selfemployed and 42 were office employees. Table 1 reports the number, age, job status, education and smoking habit of the five groups of men. The age and duration of the total working activity of the five groups was similar. The education level of the workers in construction yards was lower than that of those working in factories, in hospitals or as craftsmen, while the education level of the office employees was higher, since most of them had a high school degree. The smoking habits of the groups of workers were similar.

Workers taking drugs or suffering from diseases were not recruited for the study. Between 08:00 and 10.00 a.m., blood was collected from the antecubital vein into heparinized tubes.

The lymphocyte number was determined by con- ventional electronic analysis, while $\mathrm{T} \mathrm{CD}^{+}$and CD $16^{+} \mathrm{NK}$ cells were determined by flow-cytometry (9). For the determination of NK activity, peripheral blood mononuclear cells (PBMCs) were separated from peripheral blood. The K562 human erythroleukemia cell line was used as target for NK cell cytotoxicity according to Reale et al. (10). Blood NK activity was determined per $\mathrm{ml}$ of blood as well as per NK cells and lymphocytes.

Before the blood sample collection, the recruited workers filled in the questionnaires in a quiet room. State-trait-anxiety inventory (STAI) was used in scale 1 , to measure state-anxiety as a temporary and varying condition, and in scale 2 , to monitor traitanxiety, as a relatively fixed tendency of the personality (11). Occupational stress was analyzed by the Italian version of the Karasek's Job Content Questionnaire (JCQ) $(12,13)$ composed of 49 items: 9 items determined the decision latitude (skill decision + decision authority) (DL), 8 items determined the macro level decision authority, 14 job demand (JD), 12 social support (SS) and 6 job insecurity. Job strain was determined by the ratio JD/DL.

Analysis of the data was performed by the Statistical Package for Social Science (SPSS 11.5 for Windows).

Table 1

Age, professional characteristics, education, and smoking habits of male workers employed in different jobs

\begin{tabular}{|lccccc|}
\hline & $\begin{array}{c}\text { Factory } \\
\text { workers }\end{array}$ & $\begin{array}{c}\text { Construction } \\
\text { workers }\end{array}$ & $\begin{array}{c}\text { Hospital } \\
\text { Attendants }\end{array}$ & $\begin{array}{c}\text { Craftsmen } \\
\text { (self-employed) }\end{array}$ & $\begin{array}{c}\text { Office } \\
\text { employees }\end{array}$ \\
\hline No. & 40 & 18 & 20 & 14 & 42 \\
\hline Age (years) (mean \pm S.D.) & $48.5 \pm 7.5$ & $46.6 \pm 6.5$ & $50.6 \pm 7.3$ & $46.8 \pm 6.9$ & $47.0 \pm 7.0$ \\
\hline $\begin{array}{l}\text { Duration of working activity } \\
\text { (months : mean } \pm \text { S.D.) }\end{array}$ & $319 \pm 98$ & $338 \pm 103$ & $328 \pm 92$ & $296 \pm 76$ & $328 \pm 118$ \\
\hline $\begin{array}{l}\text { With high school degree } \\
\text { (No.) }\end{array}$ & 21 & 3 & 8 & 7 & 32 \\
\hline $\begin{array}{l}\text { Current smokers (No.) } \\
\text { n }\end{array}$ & 30 & 13 & 15 & 10 & 31 \\
\hline
\end{tabular}

\section{Results}

The analysis of the data showed significant differences in the levels of state and trait anxiety in the five groups of workers (table 2). STAI 1 of the craftsmen was lower than that of the construction workers $(p<0.05)$ and of the office employees $(p<0.05)$, while
STAI 2 of the craftsmen was lower than that of the other groups [workers in construction yards $(\mathrm{p}<0.05)$, hospital attendants $(\mathrm{p}<0.05)$, office employees $(p<0.01)$ and factory workers $(p<0.001)]$; moreover, STAI 2 of the workers in factories and in hospitals was significantly lower $(p<0.05)$ than that of the construction workers. 
Table 2

STAI 1, STAI 2, job demand (JD), decision latitude (DL) job strain (JD/DL), social support, job insecurity and subjective symptoms mean scores of male workers employed in different jobs

\begin{tabular}{|lccccc|}
\hline & $\begin{array}{c}\text { Factory } \\
\text { workers } \\
\text { (a) }\end{array}$ & $\begin{array}{c}\text { Construction } \\
\text { workers } \\
\text { (b) }\end{array}$ & $\begin{array}{c}\text { Hospital } \\
\text { attendants } \\
\text { (c) }\end{array}$ & $\begin{array}{c}\text { Craftsmen } \\
\text { (self- } \\
\text { employed) } \\
\text { (d) }\end{array}$ & $\begin{array}{c}\text { Office employees } \\
\text { (e) }\end{array}$ \\
\hline STAI 1 & $34.4 \pm 8.1$ & $37.6 \pm 5.0^{\mathrm{d}}$ & $34.2 \pm 5.2$ & $32.3 \pm 2.8^{\text {be }}$ & $34.7 \pm 5.6^{\mathrm{d}}$ \\
\hline STAI 2 & $31.4 \pm 6.7^{\mathrm{bd}}$ & $34.5 \pm 6.4^{\text {ad }}$ & $31.8 \pm 4.7^{\mathrm{d}}$ & $26.9 \pm 4.3^{\text {abce }}$ & $33.6 \pm 7.3^{\mathrm{d}}$ \\
\hline Job Demand (JD) & $31.2 \pm 3.2^{\mathrm{e}}$ & $33.2 \pm 4.2^{\mathrm{de}}$ & $31.3 \pm 4.3^{\mathrm{e}}$ & $29.6 \pm 5.0^{\mathrm{b}}$ & $28.4 \pm 5.4^{\mathrm{abc}}$ \\
\hline Decision Latitude (DL) & $62.5 \pm 9.5^{\mathrm{de}}$ & $62.7 \pm 7.6^{\mathrm{de}}$ & $66.2 \pm 8.9$ & $76.0 \pm 10.2^{\mathrm{ab}}$ & $70.2 \pm 12.0^{\mathrm{ab}}$ \\
\hline Job strain (JD/DL) x 10 & $51.5 \pm 11.1^{\mathrm{de}}$ & $53.7 \pm 9.7^{\mathrm{de}}$ & $48.2 \pm 9,6^{\mathrm{de}}$ & $39.7 \pm 7.8^{\mathrm{abc}}$ & $41.5 \pm 10.7^{\mathrm{abc}}$ \\
\hline Social Support & $23.6 \pm 3.6$ & $23.8 \pm 3.3$ & $24.5 \pm 4.0^{\mathrm{e}}$ & $26.1 \pm 4.7$ & $23.4 \pm 3.7^{\mathrm{d}}$ \\
\hline Job insecurity & $11.5 \pm 3.4$ & $11.3 \pm 2.9$ & $10.1 \pm 1.7$ & $10.4 \pm 2.5$ & $9.8 \pm 3.0$ \\
\hline
\end{tabular}

Values are means + S.D

Kruskall-Wallis: statistical significant differences $(\mathrm{p}<0.05)$ vs workers in factories $(\mathrm{a})$, construction workers $(\mathrm{b})$, hospital attendants $(\mathrm{c})$, craftsmen (d), employees in offices (e)

The job demand (JD) of the office employees was lower than that one of the workers in factories $(p<0.001)$, in construction yards $(p<0.001)$ and in hospitals $(p<0.05)$, while the JD of the craftsmen was significantly lower only than that of the construction workers $(p<0.01)$. The decision latitude (DL) of the workers in construction yards and factories was lower than that one of the craftsmen $(p<0.001)$ and of the office employees $(p<0.01)$.

The job strain (JD/DL) of the craftsmen and of the employees was lower than that of the workers in construction yards $(\mathrm{p}<0.001)$, factories $(\mathrm{p}<0.001)$ and hospitals $(\mathrm{p}<0.05)$.

Moreover, social support of the craftsmen was higher than that expressed by of the office employees $(\mathrm{p}<0.05)$.

Blood cytotoxic activity per $\mathrm{ml}$ of blood and per lymphocytes of the factory workers was significantly lower $(\mathrm{p}<0.05)$ than that one of the craftsmen and of the office employees (figure 1). Blood cytotoxic activity/CD16+ NK cells of the same factory workers was significantly lower than that one of the hospital attendants $(p<0.05)$, craftsmen $(p<0.01)$ and office employees $(\mathrm{p}<0.001)$.

Blood cytotoxic activity/CD16 ${ }^{+} \mathrm{NK}$ cells and per lymphocytes of the construction workers was lower than that one of the craftsmen $(p<0.05)$ and of the office employees $(\mathrm{p}<0.01)$

Moreover, blood cytotoxic activity/CD16 + NK cells of hospital attendants was either significantly lower $(p<0.05)$ than that of the office employees and higher $(p<0.05)$ than that of the factory workers.

\section{Discussion}

This study evidences differences in blood NK activity, among men with different job stress (dependent on the type of employment). The craftsmen and the office employees were the groups with lower perception of anxiety and occupational stress and higher NK activity. On the contrary, the men working in factories and in the construction yards showed lower levels of the score of psychological parameters and lower NK immune response than the other groups.

The men working as attendants in hospitals showed slightly elevated perception of anxiety and stress and slightly reduced blood NK activity in relation to the craftsmen and the office employees. Regarding this, it was reported that increased work load and shift works, in emergency doctors and nurses, may affect the immune response, including blood NK activity $(7,8)$. This investigation was carried out on a group of male workers with a stable job 
position and low perception job insecurity. For this reason, job insecurity was not a stress stimulation in the recruited participants.

It is known that anxiety and depression, which are generally correlated, are included among the factors which reduce blood NK activity $(1,2,4)$. However, all the workers recruited for this study evidenced levels of anxiety in the normal range in relation to those ones reported in previous investigations $(6,9,14)$. Therefore, the type of job and not anxiety and/or perception of job insecurity could have played an important role in affecting blood NK activity in this study. However, it may not be excluded that the different social level and life style may have influenced the choice of the employment. In particular, the construction workers presented a lower level of education. With regard to this, the "healthy worker effect", by which healthy workers achieve more stimulating and gratifying positions (15), may have played an important role in the selection of the different types of job.

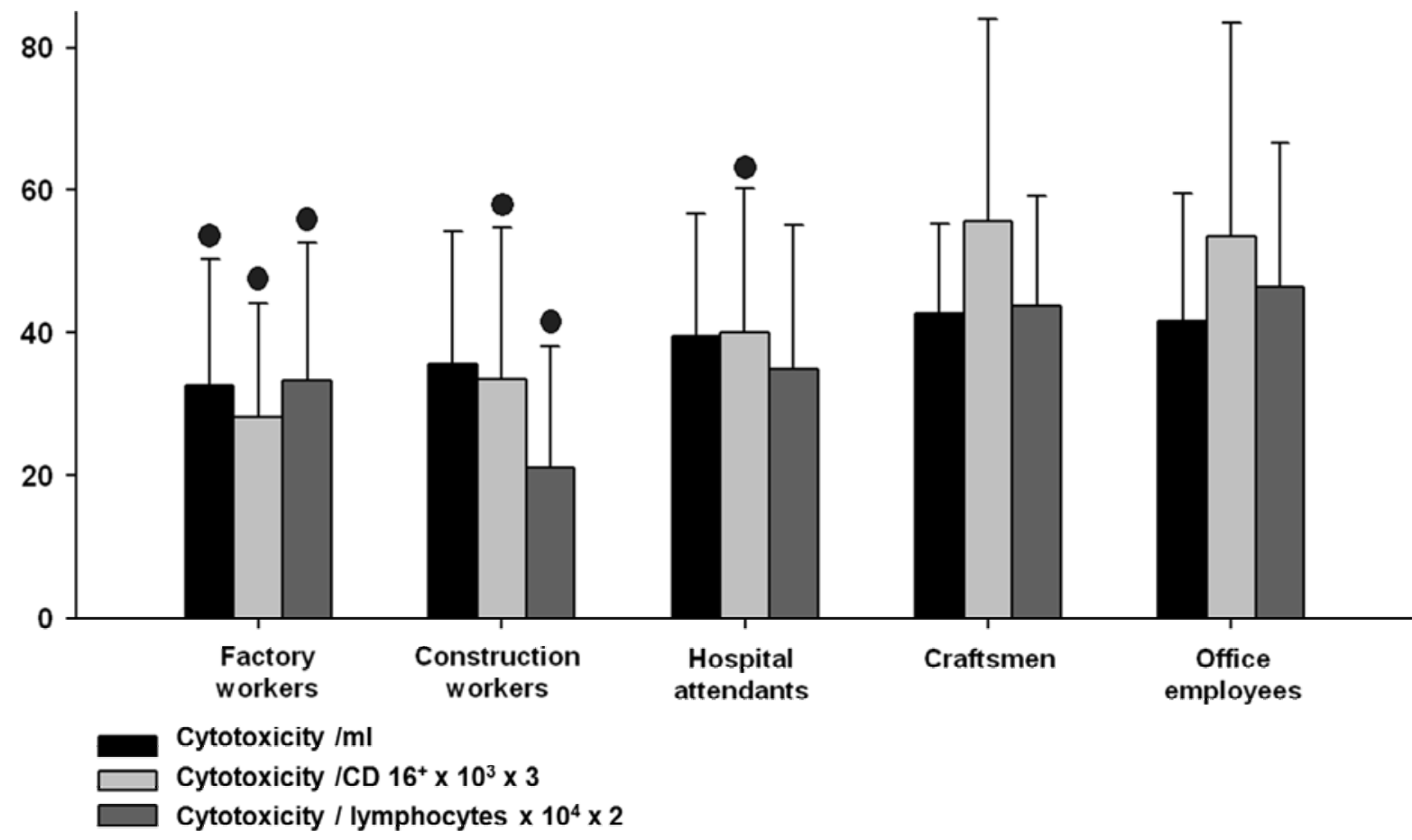




\section{References}

[1] K. Morimoto and T. Takeshita, C. Inoue-Sakurai and S. Maruyama . Lifestyle and mental health status are associated with natural killer cell and lymphokine activated killer cell activities. Sci Total Environ 270 (2001), 3-11

[2] P. Boscolo, M. Di Gioacchino, M. Reale, R. Muraro and L. Di Giampaolo. Int J Immunopathol Pharmacol. 24, suppl 1 (2011), 51-54

[3] P. Boscolo, P. Youinou, T.C. Theoharides, G. Cerulli, and P. Conti. Environmental and occupational stress and autoimmunity. Autoimmunity Rev 7 (2008), 340-345

[4] S.J. Schleifer, S.E. Keller, J. Bartlett, H.M. Eckholdt and B.R. Delaney. Immunity in young adults with major depressive disorder. Am J Psychiatry 153 (1996),477-482.

[5] F. Cohen, M.E. Kemeny, L.S. Zegans, P. Johnson, K.A. Kearny and D.P. Stites. Immune function declines with unemployment and recovers after stressor termination. Psychosom Med 69 (2006), 225-234

[6] L. Forcella, A. Di Donato, S. Reversi, E. Fattorini and P. Boscolo. Occupational stress, job insecurity and perception of the health status in Italian teachers with stable or temporary employment. J Biol Regul Homeost Agents 23 (2009), 85-93.

[7] Y. Morikawa, K. Kitaoka-Higashiguchi K, Tanimoto C et al. A cross-sectional study on the relationship of job stress with natural killer cell activity as natural killer cell subsets among healthynurses. J Occup Health 47 (2005),:378-383.

[8] H. Okamoto, T. Tsunoda, K. Teruya et al.. An occupational health study on emergency physicians in Japan: health assessment by immune variables (CD4, CD8,
CD56 and NK cell activity) at the beginning of work. J Occup Health 50 (2008), 136-146.

[9] P. Boscolo, A. Di Donato, L. Di Giampaolo, L. Forcella, M. Reale, V. Dadorante, F. Alparone, S. Pagliaro, M. Kouri, A, Magrini A and E. Fattorini Blood natural killer activity is reduced in men with occupational stress and job insecurity working in a university. Int Arch Occup Environ Health 82 (2009), 787-794.

[10] M. Reale, P. Boscolo, V. Bellante, C. Tarantelli C, M. Di Nicola, L. Forcella, Q. Li, K Morimoto, and R. Muraro, Improvement of NK natural killer activity by lactobacillus casei Shirota in male healthy smokers $\mathrm{Br} \mathrm{J} \mathrm{Nu}-$ trion (in press)

[11] C.D. Spielberger. Inventario per l'Ansia di Stato e di Tratto (Italian Version). O.S. Organizzazioni Speciali, Firenze, 1989

[12] R.A. Karasek, C. Brisson, N. Kawakami, I. Houtman, P. Bongers and B. Amick. The Job Content Questionnaire (JCQ). An instrument for Internationally Comparative Assessment of Psychosocial Job Characteristics. J Occup Health Psychology 3 (1998), 322-355.

[13] A. Baldasseroni, D. Camerino, P. Cenni, G.C. Cesana, E. Fattorini, M. Ferrario, M. Mariani and R Tartaglia. La valutazione dei fattori psicosociali - Il Job Content Questionnaire. Fogli d'Informazione 3 (2001), 20-32.

[14] Di Donato A, Di Giampaolo L, Reale M et al. Effect of occupational stress and anxiety on natural killer lymphocyte activity of men and women employed in a university. Int J Immunopathol Pharmacol 2006; 19(4s):79-84.

[15] N. Pearce, H. Checkoway and C. Shy. Time-related factors as potential confounders and effect modifiers in studies based on occupational cohort. Scand J Work Environ Health 12 (1986) :97-107. 